\title{
Editorial: "The Enemies of All Mankind" and, Will the Real Villains Please Stand Up!
}

\author{
Ananthakrishnan Aiyer • Kirk Dombrowski • \\ Anthony Marcus
}

Published online: 18 March 2010

(C) Springer Science+Business Media B.V. 2010

The list of self-proposed state forms is becoming overwhelming-theater states and puppet states, oil states and failed states, religious states and bandit states, and the Cheshire-cat state of all those so-called "state-less zones" in Africa. If there were an academy awards ceremony for state-form pretention, the list of nominees for 2010 would already be long.

For best supporting actor in a revolutionary farce, we might nominate Washington, DC for its role in the ongoing political soap-opera that is Iran. In the latest episode, a revanchist-whacko-mullah regime is attempting to crush popular support (among college students of course) for a loyal former Khomeini supporter who remains completely in the back pocket of Iranian kingmaker Ayatollah Akbar Hashemi Rafsanjani, even while crying over a stolen election. In this role he is dubiously aided by equally bizzaro war talk by Washington, DC, which in turn gives current President Ahmadinejad all the legitimacy and justification he needs to ramp up the internal purges.

Then there is the musical pair of EU-Israel. In our favorite sit-down-Jack-Bauer example of life imitating art, we have the Munich inspired political assassination of Hamas senior military official Mahmoud al-Mabhouh by the Israeli Mossad, using the forged passports from stolen identities of Europeans living in Israel. We have to say, though, that for those of us giving out the Awards, it is unclear whether the Mossad is better in its role as Inspector Clouseau, or Britain in its role as Captain Louis Renault (we too are "shocked, shocked to find murder going on here"). Of course thinking of Jack Bauer, maybe that is what they wanted us to think.... hmmm.

Such spy-versus-spy questions are usually too sophisticated for editor-types, and so we thought instead that we might give a nod to that genre of state performance that seemed all the rage only a few short months ago. So from the

A. Aiyer $(\bowtie) \cdot$ K. Dombrowski · A. Marcus

University of Michigan, Flint, Flint, MI, USA

e-mail: anantha.aiyer@gmail.com 
Captain-Jack-Sparrow-where-are-you-when-we-need-you category, the nomination for "worst posturing in a superpower leader" goes to Barack Obama, President of the US, for his arrest and planned trial of Indian Ocean "pirate" Abdiwali Abdulqadir Musé.

For those who have not kept up with events on the high seas, Musé will be the first person to be tried on charges of piracy in US courts in almost a century and a half (the last prosecution was in the 1870s). The details of the case are still a bit unclear, but as most CNN watchers will recall, he is accused of being the ringleader of the group of "pirates" that took over the tanker Maersk Alabama and held the crew hostage from April 8, 2009 until it ended a few days later when most of the pirates were killed by Navy sharpshooters. On May 19, 2009, at about the same time that Captain Richard Philips was being touted as an international hero for ordering his men to hide while he confronted what the New York Daily News referred to as "the buccaneers", Musé was indicted in U.S. courts in New York. His tragicomic smiling/grinning face was immediately posted on all news feeds with indications that despite his terrorizing activities, he really loved "America." His mother, Adar, who makes a meager living by selling milk in the market of the town of Galkayo, appealed to Obama to release him given his teenager status (something that has been questioned by the US authorities_-indeed, no one seems to be sure about his age). She also expressed: "I was delighted when I heard that my son is in the hands of the Americans because I know America has huge respect for human rights."1

Unfortunately for Musé's mother, her pleas and hopes have been squashed on both fronts. First, President Obama, specifically used this event, in his Nobel Prize acceptance speech, to link Somali piracy to Afghanistan, war, pillage, threat, and righteous simmering anger: "America's commitment to global security will never waver. But in a world in which threats are more diffuse, and missions more complex, America cannot act alone. America alone cannot secure the peace. This is true in Afghanistan. This is true in failed states like Somalia, where terrorism and piracy is joined by famine and human suffering. And sadly, it will continue to be true in unstable regions for years to come." Given earlier bombastic statements by Hillary Clinton on clamping down on this new web of piracy-terrorism-money laundering connections, it looks like Musé will be made an example of the penalties in store for those who try to obstruct the free and smooth circulation of commodity capital in Africa, or anywhere else for that matter.

Secondly, the US government, that long champion of "human rights," indicted Musé in Federal court in Manhattan on January 12, 2010 on ten different criminal counts, four of which carry mandatory life sentences. The most crucial offense being the charge of "piracy under the law of nations." It is nice to know that Cicero's words still carry weight in our post-postmodern times, and that these "enemies of all mankind" (represented by Musé) will become the flexible new front of the moving war on terror.

So how did a Somali teenager ever land this role of a lifetime, or several lifetimes apparently, and wind up starring as the fall guy and poster child for the latest stage

\footnotetext{
1 http://www.newsvine.com/_news/2009/04/20/2709152-mom-of-pirate-in-us-custody-pleads-for-hisrelease, accessed December 29, 2009.
} 
of the US global war for governance? Or, more broadly, how did such a drama come to be set in Somalia (the Barbary Coast of our age?)? ${ }^{2}$ Why, when, and how did that happen? We mean, seriously, pirates? In Somalia?

Of course it is always hard to tell if pirates are serious, and here Musé fits the bill perfectly-much to the consternation of those who seek to hang him. But just as strange is the choice of locale. If you read mainstream explanations-and here there is a strong convergence between the mass media and the US State Department- the real issue behind these scourges of the high seas has actually to do with the oftrepeated mantra of "failed states" normally found in the company of such disreputable characters as warlords, Islamic militants, corruption, famine, and, of course, Al-Qaeda. All well and good, and the Indian Ocean does seem a nice, out-ofthe-way place for a sail, but like those seemingly pesky jet contrails that flit inconveniently on the screen of so many parables set in that era of the American Golden age, there is quite a different story being told in the background than that being staged on the set. After all, we saw Black Hawk Down, and there was not a pirate in sight. Where did all these pirates come from, in such a short time?

So, in the spirit of inconvenient Hollywood anachronism, we offer this very brief and undersourced introduction to the pirates of our age, and hope it will inspire colleagues to engage in a more thorough discussion of this region and its problems and prospects in the pages of future issues.

For all intents and purposes, Somalia's previously "unfailed" state took the form of a military dictatorship under Mohammed Sayed Barre. Barre, after a brief flirtation with "scientific socialism" from 1969 to 1974, found Washington greenbacks more compelling than Moscow gold and became an important Cold War client of Uncle Sam in the Horn of Africa. But like many such leaders who found themselves out in the cold in the early 1990s, Barre was ousted in 1991, reportedly as a result of entrenched corruption and an inability to manipulate clan rivalries (all of which he seemingly managed quite well while the greenbacks were flowing in rivers). His departure and the national bankruptcy he left behind made way for the better-known Mohammed Farah Aideed. Alternately warlord, clan leader, king fora-day, invisible man, and finally one among many, Aideed managed what was left of the Somali state machinery, even while (as Amartya Sen would put it) the entire nation lost its entitlement to sell their labor at a rate on which they could subsist. The result of such an imbalance in the way labor is valued across the globe created what came to be called a "humanitarian crisis" (of course there are other terms for it), which in turn further fanned the flames that George Bush Sr. needed to intervene before he left office.

Bush, who rode into office on a campaign that famously featured convicted murderer/rapist and archetypal African American "ghetto super-predator" Willie Horton, actually seemed more concerned with extending his drug/crime agenda into East Africa than with the roots of starvation in a country that continued to export food amid famine. Rather shortly after arriving in Somalia, he sought to use the US

\footnotetext{
${ }^{2}$ Early US state-formation and efforts to assert their importance in the Atlantic World were, in fact, closely tied to fighting Barbary Coast "pirates," and many early caricatures of "Islamist" piracy come from this time period, 1776-1815. For a highly readable account, see Lambert 2005.
} 
military to stamp out the illegal trade in qãt (a mild stimulant similar to coca leaves chewed in the Andes). Such an intervention threatened one of the few forms of organized livelihood in the country, of course, and one which brought much needed foreign currency from across the Straits and further south to a place where local currencies were as useless in world markets as the labor they represented. Naturally, Bush's police efforts were roundly resisted by those whose livelihoods were on the line, and in the US, the ideological basis of the grab-bag intervention (citing everything from failed states to Islamic militancy and illegal weapons sales) left the American public with little tolerance for the number of casualties that started piling up. After the downing of four helicopters and the death of 18 US Army Rangers (enshrined by Ridley Scott in Black Hawk Down) in 1993, US forces left abruptly.

The political situation in Somalia further degenerated as Aideed's rule crumbled. Differing factions within Somalia sought to establish their own sway over different parts of the country and "friendly" neighbors like Ethiopia tried to grab Somali territories with access to the sea. Once the embassy bombings of 1998 in Nairobi and Dar es Salaam were "linked" to Somali groups, after 9/11 2001, Somalia's international status was upgraded to a "high-profile" area, where, we were assured, just about every stalking horse for contemporary moral panic suddenly seemed to flourish: Al-Qaeda, disgruntled youth, corruption, lawlessness, and Islamic militancy among unruly Africans (Naylor 2006:120-136). Yet despite all the talk of a conflict-ridden, devastated and morally suspect landscape, one which, it was seldom mentioned, forced thousands to seek shelter in the cities along the sea, and many more into exile in refugee camps in neighboring countries, one rarely heard about the threats posed by Somali piracy, at least not until 2004. Enter Abdiwali Abdulqadir Musé, and hundreds other like him.

The sea around Somalia has always provided a means of livelihood for the fishing communities that live there. Even after their numbers increased (as thousands of pastoral nomads migrated there during the droughts, famines, and proxy-wars of the mid-1970s and 1980s), fishing provided coastal communities a stable means of making a living - a place where one's labor could still be exchanged with the environment and others for the means necessary to get through another day. However, since 1992, when the Somali navy disappeared (along with the central state), foreign trawlers began encroaching on the seas of Somalia, bringing capital intensive fishing methods that had already by that time devastated the fishing grounds of the North Atlantic and seas as far away as Alaska, Fiji, the Antarctic shelf, and much of the ocean east of New Zealand.

For close to 12 years, these trawlers from primarily EU and East Asian countries practiced the same strategy that worked so well elsewhere, resulting in a massively depleted fishing stock perhaps even past the point of any future recovery. According to an EU study, the estimated value of illegal fishing from sub-Saharan Africa is about one-to-two billion US dollars a year, far more than the trade in qãt and stolen relief supplies put together. Needless to say, the local fishing economy suffered intensely, caught between the rock of disappeared stocks and the hard place of population movements from the interior. But unlike the foreign fleets with whom they competed, these communities could not simply move on to pillage anew 
someplace else. Instead, they were left to pillage where they were, a dubious prospect in an age of highly mobile capital (and militaries).

In their efforts, they have remained hopelessly small-time. If it is true that Somali "pirates" made about $\$ 80$ million from ransom payments last year, which we doubt, this still amounts to less than $10 \%$ as taxes or "tribute payments," on the "illegal fishing" that continues to flourish, without a hint of international community concern for arresting, trying, punishing, or wresting reparations from these resource thieves. Indeed, since there is no Somali navy, it appears that many, if not most, of the "pirates" are simply claiming a share of what is rightfully theirs to begin with, and which is being stolen from them in broad daylight (Waldo 2009)!

Despite a stream of complaints from Somali fishermen and several political leaders to the UN and EU about the disappearing fish stocks, absolutely no action was ever taken. The enlightened EU media has simply refused to shine a light on this topic (it might provoke some gastric ulcers in a public that is busy chomping down on rock lobsters). ${ }^{3}$

But illegal fishing was only part of the story of the theft and destruction of Somali livelihoods. The other part of this story has to do with dumping chemical and nuclear waste in the region. African seas and coastlines have long been a favored destination of EU and US waste dumping, and Somalia is no exception. It is not clear how much Somalis knew about the dumping of toxic wastes as it occurred. Things changed, though, after the tsunami of 2004, which churned up and brought to light disturbing hijinx across the Indian Ocean. As one United Nations study puts it:

...Somalia is one of the many Least Developed Countries that reportedly received countless shipments of illegal nuclear and toxic waste dumped along the coastline. Starting from the early 1980s and continuing into the civil war, the hazardous waste dumped along Somalia's coast comprised uranium radioactive waste, lead, cadmium, mercury, industrial, hospital, chemical, leather treatment and other toxic waste. Most of the waste was simply dumped on the beaches in containers and disposable leaking barrels which ranged from small to big tanks without regard to the health of the local population and any environmentally devastating impacts. ${ }^{4}$

The few who have followed the story link it to the Italian Mafia's new-found fondness for Somali fish (the cover for dumping provided by bogus agreements with Somali warlords for local imports and exports), and dumping the EU's waste off Somalia's coast. Europeans can sleep well knowing that radioactive waste is far away, foreign currency circulates in Somali political circles, and people along the coast see a dwindling resource poisoned by development. Put plainly, the spike in "Somali piracy" thus emerged in 2005 as fishing communities, ravaged by tsunami, toxic waste dumping, and declining resources attempted to tap into those nearby global flows of currency that seemed, as it were, just on the horizon.

\footnotetext{
${ }^{3}$ The only journalist to raise this issue was Johann Hari on January 5, 2009 in The Independent. See http://www.independent.co.uk/opinion/commentators/johann-hari/johann-hari-you-are-being-lied-to-aboutpirates-1225817.html, accessed April 15, 2009.

4 http://www.unep.org.bh/Publications/Somalia/TSUNAMI_SOMALIA_LAYOUT.pdf, accessed Jan 12, 2010.
} 
The response of the "community of nations" to these somewhat irregular livelihood strategies-nations which include, among others, Italy, France, Spain, Greece, Russia, Britain, Ukraine, Japan, South Korea, Taiwan, India, Yemen, Egypt - has been to use the UN to take punitive action against the least powerful of the actors in this tragic-comic B movie: the Somalis coastal villagers themselves. The pinnacle was achieved with Musé's state-sanctioned kidnapping, a first, but probably not a last, for the Obama administration. Not to be outdone, just last month a Chinese general announced China's interest in building a naval base in that part of the world. His reasoning: to protect China's trade routes which are so clearly under threat from piracy. While this perhaps bodes well for new bilateral ties between the US and China, the announcement also sent shivers through the US Navy as it appeared to be further proof of China's imperial ambitions, and which may put Somalia near the center of a new "great game." Now that Somalia is being talked about in the same breath as Yemen, the next object of the war on terror, it surely portends the beginning of a rosy Sino-American relationship.

As several scholars have documented historically, maritime piracy had two aspects to it: it was involved in empire building and capital accumulation in its ties to mercantilism (Sir Francis Drake, anyone!) but it also held radical possibilities as many "pirates" sought to create autonomous and egalitarian orders (Rediker 2004). ${ }^{5}$ We are a far cry from both those dynamics in Somalia, which makes us wonder, again, whether Somalia is entirely miscast in this role. Certainly there are others with more worthy claims. In the past decade, piracy has made a comeback as a form of collusion between state and capital in the realm of bio-piracy; as swashbuckling "anarchist" and "libertarian" impulses in the realm of electronically traded music and film (manifested most recently by the Swedish founders of Piratebay.org, a website where middle-class kids with access to computers and the Internet can up/ download music, films, and the like, all the while saying "Got You" to Capital and governments); to the financial shenanigans of that old Jolly Roger (who might have originally been a pirate of Tamil origin-Ali Raja?) of Wall Street, the corporate arbitrageur.

Somali "piracy" is of a completely different matter, though. The "pirates" are young, lightly armed black men, from a stateless society, who are neither aiding capital accumulation nor romantic enough to be counted as swashbucklers for the twenty-first century (although there appears to be sizeable support for their activities in Somalia itself since they are acting as a kind of Citizens' Coast Guard). At best, what is happening off the Somali coast can be analyzed as an effort to normalize a tributary form of production in an area that has been abandoned by the benefits of global capitalist investment. At minimum, it can be seen as evidence of how desperate Somali fishermen have been made by recent events. And to be sure, we are not suggesting that these activities represent any kind of meaningful political or economic practice that is sustainable in the long run. However, it would behoove us to understand their desperate activities as cries of a population that has been punished for a long time.

\footnotetext{
${ }^{5}$ For a concise and well-written overview of representations of pirates from the eighteenth century through Disney, see Parker (2009).
} 
Unlike the swelling informal/illegal proletariat of the urban slums across the world, in Somali cities not even such shadowy livelihood activities are possible. Hence the turn to the sea-a space, the "pirates" assumed (wrongly) was beyond the reach of international law. Like their counterparts in Gaza, New Orleans, Tijuana, Manila, or any number of myriad places, they are the nameless and faceless fodder for the brutal machinery of our times. Ironically or tragically, depending on one's point of view, Musé, if convicted, will live longer than his fellow travelers or their counterparts in the rest of the world.

While none of our contributors to this issue address piracy directly, much of the work that follows touches on some of these same themes. This issue features a dialogue between Carolyn Nordstrom and Anton Blok on the issue of failed states and corruption; a discussion of the events of the recent Iranian election by Manuchehr Sanadjian, and an extended forum on "corporate oxymorons" organized by Stuart Kirsch and Peter Benson, where questions of media, capital, image and damage combine in the newspeak of the day. We also include a book review by Dan Labotz, an extended review essay by Tom Brass, and six poems by klipschutz.

\section{References}

Lambert, Frank. 2005. The Barbary wars: American independence in the Atlantic world. New York: Hill and Wang.

Naylor, Ralph. 2006. Satanic purses: Money, myth, and misinformation in the war on terror. Montreal: Mc-Gill-Queen's University Press.

Parker, Martin. 2009. Pirates, merchants and anarchists: Representations of international business. Management and Organizational History 4(2): 167-185. http://moh.sagepub.com/cgi/content/ abstract/4/2/167. Accessed Jan 15, 2010.

Rediker, Marcus. 2004. Villains of all nations: Atlantic pirates in the golden age. Boston: Beacon.

Waldo, Mohammed Bashir. 2009. The two piracies in Somalia. Wardheer News. http://wardheernews. com/Articles_09/Jan/Waldo/08_The_two_piracies_in_Somalia.html. Accessed December 18, 2009. 